


\title{
El arte como el Gran Rechazo: la (des)humanización de la estética
}

\section{Art as the Great Refusal: the (de)humanization of aesthetics}

\author{
José Alfonso Correa Cabrera \\ Universidad Nacional Autónoma de México, México
}

Resumen: Filósofos como Marcuse han subrayado las propiedades liberadoras del quehacer artístico. Pero si hemos de pensar el arte como el Gran Rechazo, es necesario mostrar qué rechaza el arte y con qué busca sustituirlo. Respecto a estas preguntas, existen dos respuestas antagónicas. Mientras una busca en la experiencia artística rechazar lo dado en nombre de una verdad intemporal, la otra también reniega de lo dado, pero admite el carácter provisorio de toda verdad. Aunque en apariencia sutil, esta distinción es sustancial. A partir de una lectura de Platón, muestro por qué en la primera posición no hay cabida para lo humano, y por qué de ella se desprenden implicaciones totalitarias. Para caracterizar a la segunda posición, me sirvo de la concepción estética de Octavio Paz y de la propuesta escultórica de Alexander Calder. Ambas propuestas permiten conciliar la insatisfacción que palpita en el arte con la alteridad que caracteriza a lo humano.

Palabras clave: Gran Rechazo, alteridad, equivocidad, totalitarismo, deshumanización.

Abstract: Philosophers such as Marcuse have underlined the liberating properties of artistic work. But if we are to think of art as the Great Refusal, we should show what is that that art rejects and with what it seeks to replace it. Regarding these questions, I outline two antagon- 
istic answers. While one seeks, by means of the artistic experience, to reject what is given in the name of a timeless truth, the other also denies what is given, but admits the provisional nature of every truth. Although seemingly subtle, this distinction is substantial. Drawing from a reading of Plato, I show why the first position leaves no room for humanness, and why totalitarian implications arise from it. To characterize the second position, I turn to the aesthetic conception of Octavio Paz and the sculptural proposal of Alexander Calder. Both interpretations allow us to reconcile the dissatisfaction that underlies art with the alterity that characterizes humanness.

Keywords: Great Refusal, Alterity, Equivocity, Totalitarianism, Dehumanization.

Recibido: 30 de junio de 2018 Aceptado: 15 de noviembre de 2018

Wer teilt die fließend immer gleiche Reihe Belebend ab, daß sie sich rhythmisch regt? [...] Wer flicht die unbedeutend grünen Blätter Zum Ehrenkranz Verdiensten jeder Art? Wer sichert den Olymp? vereinet Götter? Des Menschen Kraft, im Dichter offenbart.

J. W. Goethe, Fausto.

\section{La deshumanización del arte}

$\mathrm{Cl}^{\mathrm{l}}$ arte es el quehacer de los insatisfechos. El artista es el inconCforme, el que no se ciñe a la tiranía del hábito. Hay algo en su creación que hace de él un insolente. $\mathrm{Al}$ artista se le fincan cargos de impiedad ahí donde su arte pone en entredicho las jerarquías, lo acostumbrado, la recta sucesión de lo que acontece. El artista se insubordina cuando reclama el derecho a crear y a diferir de los patrones de valorización aclamados por el estado de las cosas. En 
palabras de Marcuse, la dimensión negativa del pensamiento es puesta en marcha por el arte, negando con ello la irrevocabilidad de lo dado, y sustrayéndose a las pretensiones de exclusividad del pensamiento positivo:

La tensión entre lo actual y lo posible se transfigura en un conflicto irresoluble, en el que la reconciliación se encuentra gracias a la obra como forma: la belleza como la promesse de bonheur. En la forma de la obra, las circunstancias actuales son colocadas en otra dimensión en la que la realidad dada se muestra como lo que es. Así dice la verdad sobre sí misma; su lenguaje deja de ser el del engaño, la ignorancia y la sumisión. La ficción llama a los hechos por su nombre y su reino se derrumba; la ficción muestra la experiencia cotidiana y la muestra como falsa y mutilada. Pero el arte tiene este poder mágico sólo como poder de la negación. Puede hablar su propio lenguaje sólo en tanto las imágenes que rechazan y refutan el orden establecido estén vivas (Marcuse, 2005: 92).

$\mathrm{El}$ arte se muestra insumiso frente a lo actual y se declara partidario de lo posible. El artista denuncia una falsedad consustancial a lo fáctico y se niega a consentirlo. No es por otra razón que el arte ha sido acusado repetidamente de ser tan sólo un capricho o, inclusive, una pérdida de tiempo. Al artista se le margina como un loco y se le desprecia como un paria. El orden se deleita con la obediencia, mientras que el artista ha declarado su rebelión intransigente. El arte será quizá estéril para los criterios del orden establecido, pero no es en forma alguna indiferente frente a él: "el arte contiene la racionalidad de la negación. En sus posiciones más avanzadas es el Gran Rechazo: la protesta contra aquello que es" (Marcuse, 2005: 93).

Pensar al artista como un insatisfecho no es exclusivo de Marcuse, sino que ha sido un tema recurrente para la filosofía desde hace siglos. Aristóteles lo plantea brevemente en su Poética. Para la 
concepción estética del estagirita, el artista no cuenta "lo sucedido, sino lo que podría suceder y lo posible en virtud de la verosimilitud o la necesidad" (Aristóteles, Poética: 1451a35). Mientras el historiador narra lo sucedido, el poeta narra cosas tales que podrían suceder. La poesía está más cerca de la filosofía pues habla de lo general; la historia, de lo particular (Aristóteles, Poética: 1451b 5-10). No se desprecia lo sucedido, sino que se parte de ello para presentar lo posible. Si el arte no habla sobre lo sucedido, sino sobre lo que podría suceder con verosimilitud, ello supone que no existe una única forma de ser. El arte, según Aristóteles, abre una dimensión que no es igual a lo aparente. Pero no se trata simplemente de planos diferentes, sino de un plano que es superior a otro. Lo que es no sólo difiere de lo que no es, sino que es más real.

Algo similar ocurre en la obra de Platón, donde el mundo de lo fenoménico siempre detenta un estatuto ontológico devaluado. Las categorías estéticas platónicas dan cuenta de ello. Así, la belleza terrena es a lo mucho la tenue imagen de una belleza superior. "[C] uando alguien contempla la belleza de este mundo, y, recordando la verdadera, le salen alas, y, así alado, le entran deseos de alzar el vuelo" (Platón, Fedro: 249d). En lo finito, el alma no halla la plenitud; alzar el vuelo y abandonar la insuficiencia del abajo es el requisito para su realización. La manía del enamorado toma como punto de partida la belleza mundana, pero ésta es siempre una imitación degradada: "De la justicia, pues, y de la sensatez y de cuanto hay de valioso para las almas no queda resplandor alguno en las imitaciones de aquí abajo, y sólo con esfuerzo y a través de órganos poco claros, les es dado a unos pocos, apoyándose en las imágenes, intuir el género de lo representado" (Platón, Fedro, 250b). La belleza existente no es valiosa en sí misma, sino tan sólo como un apoyo. La insuficiencia consustancial a lo mundano le impide al alma hallar aquí su plena satisfacción. En el anhelo de lo bello en sí encontramos en apariencia el Gran Rechazo. La manía 
divina efectúa un cambio en "los usos establecidos" (Platón, Fedro: 265b). Es la insatisfacción ante lo dado lo que empuja a Platón a rebasar los márgenes de lo aparente. El encomio platónico de la locura es al mismo tiempo el repudio del orden imperante.

Desde este primer punto de vista, podemos suponer que el pensamiento estético platónico supone el Gran Rechazo. Platón desprecia lo mundano y aspira a la divinidad de un plano trascendente. Pero no hay que perder de vista qué es lo que se rechaza. Anticipemos que esta subversión se logra imponiendo condiciones impagables para la humanidad. Lo dado se repudia y en su lugar se instituye lo inhumano. Las implicaciones del rechazo platónico a la belleza degradada se entienden mejor cuando se profundiza en el reino de las formas.

Despreciar lo establecido tiene como contraparte aspirar al ser. El ser ofrece rasgos diametralmente distintos a aquellos propios de la apariencia mundana. Tales rasgos son sólo concebibles en un plano supramundano, donde la ciencia no se ocupa ya de la generación, del cambio ni de lo otro: "Tiene ante su vista a la ciencia, y no aquella a la que le es propio la génesis, ni la que, de algún modo, es otra al ser en otro, sino esa ciencia que es de lo que verdaderamente es ser" (Platón, Fedro: 247d-e). Apelar al privilegio ontológico del mundo de las formas equivale a privilegiar lo inengendrado. A su vez, rechazar la generación es rechazar el cambio. La verdad es ingénita porque nunca cambia, porque se mantiene siempre igual a sí misma. No hay alternancia entre un Otro y un sí mismo. Y así como a la verdad le es ajena el devenir, el alma humana que aspira a congraciarse con ella participa en esta caracterización.

Al participar en el ser, el alma humana comparte sus principales propiedades: "necesariamente el alma tendría que ser ingénita e inmortal” (Platón, Fedro: 246a). La existencia humana cambiante es descartada en nombre de lo eterno. En su vuelta a la verdad, el 
alma ha de liberarse de sus cadenas terrenales. Pero sobre el alma pesa el yugo del cuerpo. Por lo tanto, el alma humana ha de desentenderse de su existencia carnal para aspirar a la verdad. Con lo corporal, el alma se desentiende de su prisión, de aquello que le impedía disfrutar de lo bello en sí y del ser en general: "el estigma que es toda esta tumba que nos rodea y que llamamos cuerpo, prisioneros en él como una ostra” (Platón, Fedro: 250c). Todo aquello que no es el ser intemporal aparece como una condena.

Con el cuerpo y con su contingencia el hombre se desentiende de todas esas vivencias ajenas a lo ingénito. Los recuerdos de todo lo que no es la verdad han de ser desechados. El hombre no sólo se desarraiga del mundo, sino de todo aquello que constituyó su vida mundana. Sus relaciones más íntimas con los otros cuerpos no tienen validez alguna en el tribunal del ser. Todo lo que amó es denunciado como insuficiente, como la simple apariencia de una verdad más alta. Su cultura, sus antepasados, su historia: todo lo perecedero ha de ser seleccionado y desechado por el tamiz de lo incorpóreo. La inmortalidad no sólo es la libertad respecto al cuerpo, sino también el desapego respecto a todas nuestras vivencias existenciales. (Una libertad bastante ambigua, tan ambigua e insatisfactoria como la de aquellos que son libres para vender su fuerza de trabajo al mejor postor.) El alma ya no sufre ni goza, sólo contempla. Las alteraciones anímicas son ahora un contrasentido. Bien vale preguntarnos qué le resta de humana a un alma así. Con el cuerpo y con lo generado, el hombre se libera también de sí mismo.

Pero no es sólo en su relación con lo bello y con el ser donde el hombre es empujado a desaparecer. También en la creación artística todo rasgo antropomorfo es señalado con sospecha. Para la estética platónica, los productos del arte han de ser revisados con celo en la aduana que guarda el ingreso a la república ideal. Así como el alma debía enajenarse respecto a lo engendrado para aspirar al 
reino de las ideas, la obra de arte ha de mantenerse fiel al ser para adquirir su carta de ciudadanía: "toda obra de la naturaleza, del arte o de ambos a la vez que esté bien hecha se halla menos expuesta que otras a sufrir alteraciones causadas por elementos externos" (Platón, República: 381b).

En su afán por la realización correcta, el artista platónico debe cuidarse de reproducir lo equívoco. El arte no puede ocuparse de lo aparente o se arriesga a ser culpable de fraude: "el que hace una apariencia, el imitador, decimos, no entiende nada del ser, sino de lo aparente" (Platón, República: 601b-c). Más que una crítica al concepto de mímesis, Platón pone en el banquillo de los acusados a ciertos modelos y ciertos productos de la imitación. Dada su fracasada representación de la verdad, poetas y pintores han de ser exiliados. Rechazar la triple distancia respecto al ser equivale a desaprobar a quienes toman como modelo lo mundano y su equivocidad (Platón, República: 599d).

$\mathrm{El}$ arte que toma como modelo las formas es el único que merece ser acogido en la polis platónica. Así, en Platón la superación de lo aparente que se efectúa a través del arte tiene un significado muy particular. El artista ha de renunciar a su propio mundo con tal de comulgar con lo bello. Lo bello se asocia con lo divino, lo simple, lo inalterable; lo bello no se corresponde con una humanidad contradictoria, que se muestra permanentemente oscilante, y cuya naturaleza padece la imperfección de un ser incompleto. $\mathrm{El}$ arte platónico se realiza al precio de renunciar a lo que hay en el hombre de mortal y de equívoco; el arte ha de despojarse de su contenido humano con tal de aspirar a lo bello. Si al arte ha de ser aceptado en la república platónica, antes ha de realizar concesiones significativas. El precio de su admisión es el compromiso con la imitación de aquello que es "incapaz de abandonar la forma que le es propia” (Platón, República: 380d). Con tal de evitar el exilio, el arte ha de representar lo divino y renegar la alteridad. 
Pero no es el contenido el único rasgo humano que Platón mutila en su estética. Al hombre también le son negados los derechos de autor sobre la obra de arte. Sócrates se lo señala con toda claridad a Ion: "Una fuerza divina es lo que te mueve" (Platón, Ion, 533d). El rapsoda no tiene potestad sobre sí mismo, sino que es el dócil testaferro de la divinidad. Pero la sentencia de Platón no se agota en los rapsodas, sino que abarca la cadena completa que componen los que participan en el quehacer artístico. El ser humano no participa en lo bello sino como intermediario. No es su naturaleza la fuente de lo bello, sino tan sólo su herramienta. Es la Musa quien es responsable en última instancia de lo bello. El hombre participa en la cadena de la inspiración, pero nunca es él mismo el origen: "la divinidad nos muestra claramente, para que no vacilemos más, que todos estos hermosos poemas no son de factura humana ni hechos por los hombres, sino divinos y creados por los dioses, y que los poetas no son otra cosa que intérpretes de los dioses, poseídos cada uno por aquel que los domine" (Platón, Ion: 534e). En la manifestación de la belleza, mujeres y hombres juegan el papel del poseso arrobado. Son tan sólo instrumentos a disposición de los dioses, impotentes por sí solos para crear. Así como sin manía no hay belleza, sin divinidad no hay arte que valga. No es lo mundano lo que da origen a lo bello.

Esta concepción no es exclusiva de los diálogos del periodo socrático, ni de aquellas obras donde la filiación platónica ha sido puesta en entredicho. En el Fedro, Platón se expresa de forma parecida respecto a la manía: "Aquel, pues, que sin la locura de las musas acude a las puertas de la poesía, persuadido de que, como por arte, va a hacerse un verdadero poeta, lo será imperfecto, y la obra que sea capaz de crear, estando en su sano juicio, quedará eclipsada por la de los inspirados y posesos" (Platón, Fedro: 245a-b). ${ }^{1}$

${ }^{1}$ Aquí la manía poética no es ni siquiera la relación más alta con lo divino, pues por encima de ella se encuentra la manía erótica. 
La manía es una concesión divina, no un atributo propiamente humano. Es sólo la inspiración suprahumana quien puede reclamar valor artístico para sus productos. Quien buscara humanizar el arte aspiraría tan sólo a la insipidez.

No hay cabida en la estética platónica para una belleza que se desprende de la alteridad. No podría ser de otra forma. El hombre y su imperfección, su naturaleza oscilante y su inextricable finitud, no son el origen de una idea de lo bello. Así como sería absurdo afirmar que lo engendrado produce lo ingénito, sería una necedad insistir en que es el hombre quien da origen a la belleza. El hombre es sólo un intermediario para la revelación de lo bello. La verdadera obra de arte no muestra la humana incompletud, ni surge de las pulsiones humanas. Si en el mundo de las formas prima lo inengendrado, el artista que aspira a la verdad ha de reconocerse como incapaz de crear. Tomando como modelo el reino de lo ingénito, el arte imita directa y exclusivamente lo bello. El hombre no se descubre a sí mismo en la revelación divina, pues ésta siempre parte de una instancia suprahumana. El hombre se vuelve artista a fuerza de aceptar su esterilidad.

En la filosofía platónica se opone la apariencia a las formas, lo humano a lo divino, lo corpóreo a lo inmortal, la equivocidad a lo unívoco, el cambio a lo ingénito, la alteridad al ser. Y así como lo equívoco ya ha sido proscrito tanto de la fuente como del contenido del arte, también la materia sobre la cual trabaja el artista ha de ser expurgada de esta perniciosa amenaza:

Porque es impresionante, Fedro, lo que pasa con la escritura, y por lo que tanto se parece a la pintura. En efecto, sus vástagos están ante nosotros como si tuvieran vida; pero si se les pregunta algo, responden con el más altivo de los silencios. Lo mismo pasa con las palabras. Podrías llegar a creer como si lo que dicen fueran pensándolo; pero si alguien pregunta, queriendo aprender de lo que dicen, apuntan siempre y únicamente a una y la misma cosa. 
Pero, eso sí, con una vez que algo haya sido puesto por escrito, las palabras ruedan por doquier, igual entre los entendidos que como entre aquellos a los que nos les importa en absoluto, sin saber distinguir a quiénes conviene hablar y a quiénes no. Y si son maltratadas o vituperadas injustamente, necesitan siempre la ayuda del padre, ya que ellas solas no son capaces de defenderse ni de ayudarse a sí mismas (Platón, Fedro: 275d-e).

Las letras no pueden discriminar la idoneidad de su interlocutor. La escritura nunca se guarda sus enigmas (aunque tampoco acaba de transparentarlos). De ahí que sea susceptible al capricho de la interpretación. Por sí solas, las palabras son incapaces de "enseñar adecuadamente la verdad" (Platón, Fedro; 276c), y ello resulta de su irreformable equivocidad. La obsesión por la verdad se ve contrariada ahí donde encuentra su certeza amenazada por la ambigüedad de las letras. Lo equívoco aparece como inconciliable con un ser que se presume inalterable, y es por ello que ha de ser temido. Al partidario de la verdad, las palabras le resultan hostiles por sustraerse a toda legalidad. Lo equívoco es no sólo lo que no se deja aprehender de forma concluyente, sino que es también aquello que invita insistentemente a subvertir la uniformidad. Se trata de un secreto siempre indescifrable, un secreto que "rueda por doquier". El pueblo insumiso que nunca acaba de ceñirse al orden fijado por el soberano despótico. El grupo subversivo cuyo modus operandi nunca termina por ser descifrado por el Estado. La irreverencia juvenil que siempre encuentra la manera de burlar el buen sentido de la etiqueta. La sigilosa estratagema que pone en entredicho la fatalidad del orden. La escandalosa insinuación de que la domesticación nunca es plenamente exitosa. Pero las letras son también impotentes, incapaces de responder a la violencia del intérprete: artificios vacilantes que precisan de ayuda para mantenerse de pie. Ya sea por su resistencia o por su maleabilidad, las palabras (y los signos en general) nunca se ajustan sin contratiempos a los moldes 
del orden. Las palabras siempre son el terreno en disputa, la tierra de nadie.

Ante la sospecha de equivocidad, la filosofía platónica responde refugiándose en lo inalterable. Thamus/Platón rechaza las letras ante la angustiosa ausencia de certidumbre. Una pretensión similar es la que motiva el Newspeak orwelliano. En la distopía de Orwell, la búsqueda deliberada por suprimir la equivocidad de las palabras era la consecuencia inevitable de una sociedad comprometida con el pensamiento ortodoxo (Goodthink). La univocidad era una de las condiciones de la completa supresión de la heterodoxia. Un lenguaje unívoco sólo es concebible ahí donde se presupone que existe un parámetro autosuficiente para decidir sobre la rectitud de las acciones. La perspicacia totalitaria supo distinguir que había que renegar de la alteridad con tal de legitimar la uniformidad. El celoso afán totalitario por eliminar la diferencia es el presupuesto de una lectura inequívoca de la realidad. Sólo suprimiendo la alteridad, el totalitario puede convertirse en el emisario plenipotenciario de la verdad.

Pero recelar de lo otro no es lo que se busca con el Gran Rechazo. No es suficiente afirmar que el arte niega lo dado. El arte corre el riesgo de servir disimuladamente a la totalidad deshumanizadora ahí donde desconoce al hombre como el artífice de su propia realidad. El arte que teme a lo equívoco amenaza con convertirse en esa revolución que aniquila el orden sin reconocer que el origen y el destinatario de su rebeldía son los hombres y las mujeres de carne y hueso. ¿Es posible conciliar en el arte la insatisfacción y el deseo por lo completamente otro? 
El arte y su reconciliación con lo equívoco

To me the most important thing in composition is disparity.

Alexander Calder, a Propos of Measuring a Mobile

Para sublevarse ante lo dado, el arte ha de revelar el carácter antropomorfo de la realidad. Ello podemos observarlo en las consideraciones estéticas de Octavio Paz. Así como para Aristóteles lo propio de la poesía era ir más allá de lo sucedido, el arte para Paz también transgrede el ciego transcurrir del tiempo. Se trata de la historia que trasciende la historia; lo humano que se reconoce como insuficiente pero también como posibilidad. Al poetizar, el artista no desconoce su finitud ni su temporalidad, pero se muestra insatisfecho frente a la simple sucesión de los hechos. El artista no amontona vivencias, sino que las revive en su obra. $\mathrm{Al}$ revivirlas, las reinventa: "El pasado y el presente de las novelas no es el de la historia, ni el del reportaje periodístico. No es lo que fue, ni lo que está siendo, sino lo que se está haciendo: lo que se está gestando. Es un pasado que reengendra y reencarna" (Paz, 2014: 64). No se trata de una simple narración del acontecer ni una simple referencia al pasado. El tiempo de la poesía, sin dejar de ser histórico, aspira a todos los instantes. Afirmar que el pasado reengendra y reencarna es también decir que ese pasado es diferente a sí mismo. Por medio de esta oscilación, las temporalidades se entrecruzan, y hombre y mujeres descubren que no son simples títeres dispensables para la astucia de la razón. No hay una temporalidad lineal, ni una sucesión factual inexorable. No es una instancia suprahistórica la que provoca las imágenes poéticas, sino el hombre mismo. El artista sigue rechazando la presunta necesidad de lo sucedido, pero este 
rechazo no se efectúa en nombre de la verdad, sino en nombre de la humanidad.

Al transgredir la sucesión ordenada, el artista no sólo juega con la temporalidad. Mostrar que no hay tiempo que pueda reclamar para sí el monopolio del ser equivale también a mostrar que el orden de todo tiempo es un orden fortuito. Esto se muestra con toda su claridad en el poema: "El ser imágenes lleva a las palabras, sin dejar de ser ellas mismas, a trascender el lenguaje, en tanto que sistema dado de significaciones históricas. El poema, sin dejar de ser palabra e historia, trasciende la historia” (Paz, 2014: 23). El poema es un producto histórico, pero al mismo tiempo niega la fatalidad de la historia. En esta operación se muestra la clave del Gran Rechazo. El artista se apoya en la historicidad del lenguaje, pero al mismo tiempo reclama para la palabra un más allá de ella misma. Las palabras se muestran como más que palabras. En esta conciliación de lo inconciliable, el arte muestra todo su potencial subversivo. El arte se subleva ante toda pretensión de uniformidad ahí donde revela "la identidad última de objetos que nos parecían irreductibles" (Paz, 2014: 66). Lo histórico no agota las posibilidades del ser. La configuración impuesta por la totalidad no decide de una vez por todas lo que las cosas son.

No es entonces en un plano ultraterreno donde hemos de buscar el modelo al que aspira el poeta. Es en las palabras mismas donde hemos de encontrar la insubordinación a lo prosaico. El arte libera precisamente porque reconoce la equivocidad de sus materiales. La ambigüedad no es entonces la atenuación del ser, sino el presupuesto de su posibilidad. El poeta regresa la palabra a su naturaleza equívoca, y con ello se libera a sí mismo del lastre de la ortodoxia. Esta insubordinación cimbra el edificio de la significación desde sus cimientos: "La palabra, en sí misma, es una pluralidad de sentidos. Si por obra de la poesía la palabra recobra su naturaleza original -es decir, su posibilidad de significar dos 
o más cosas al mismo tiempo-, el poema parece negar la esencia misma del lenguaje: la significación o sentido" (Paz, 2014: 47-48).

Esta negación del sentido es sólo aparente. Lo que el artista niega en realidad es la definitividad del sentido imperante. El poeta no mutila la palabra, sino que le devuelve la plenitud de su valor. El acontecimiento generado por el poeta no es la perversión, sino la purificación de la palabra; se trata de la vuelta al origen, de la Revolución. Según Paz, la poesía, ya sea como palabra sonido o color, a diferencia de la manipulación técnica y la prosa, no violenta su materia buscando la univocidad. Ella conserva la pluralidad de sentidos, la ambigüedad del signo. Regresa sus materiales a lo que son, les recobra su esplendor equívoco. Además, convierte su materia en imágenes. Sin dejar de ser lenguaje, va más allá del lenguaje: "En el poema el lenguaje recobra su originalidad primera, mutilada por la reducción que imponen prosa y habla cotidiana. [...] La palabra, al fin en libertad, muestra todas sus entrańas, todos sus sentidos y alusiones" (Paz, 2014: 22).

Esta conversión no está exenta de recriminaciones. Quienes fetichizan la ley no pueden sino mostrarse enfurecidos donde sus certezas ya no aparecen como naturales, sino como una simple arbitrariedad. Si el albur impacienta a los mojigatos, ello se debe a su impenitente ambivalencia. Lo equívoco es escandaloso precisamente porque altera lo acostumbrado. El poeta es acusado de ininteligible y de rebuscado; su obra aparece como una anormalidad y es censurada por su extravagancia. El fanatismo funcionalista rabia cuando los objetos controvierten el movimiento mecánico de la totalidad: "Separadas de sus funciones habituales y reunidas en un orden que no es el de la conversación ni el del discurso, las palabras ofrecen una resistencia irritante. Toda creación engendra equívocos" (Paz, 2014: 43). Violentada por el ciego acontecer, la palabra se ha de ajustar al orden de "lo normal". Lo prosaico, el suceder cotidiano, impone a los materiales un cierto patrón al que 
han de ajustarse. Pero ahí donde aparece la revelación poética, toda certeza se tambalea.

El arte no sólo libera los materiales de las sujeciones funcionalistas. El poeta desata los lazos que sujetan las palabras a lo prosaico. Pero este ejercicio no encuentra en los signos su razón de ser, sino en el hombre mismo. En última instancia, lo que el arte busca desvelar no es tanto la originaria ambivalencia de sus materiales, sino la naturaleza indeterminada de su creador. Siguiendo a Paz, el hombre que poetiza da un salto mortal, pues se suspende a sí mismo sobre el abismo de la creación. Es en este salto donde el hombre se reúne con la alteridad. Al reencontrarse con el otro, el poeta comulga con la esencial heterogeneidad del ser. Pero ese otro que se revela en la experiencia poética siempre es el hombre mismo (Paz, 2014: 137). Así la vivencia del ser y el quehacer artístico no son ya dos opuestos irreconciliables. Y si es que resulta posible conciliarlas, ello no es resultado del ciego azar, sino de lo que ambas tienen en común: el ser humano.

Mostrar que en el hombre palpita una alteridad originaria equivale a señalar que no existe nada más propio de él que lo posible. La libertad no es más la eterna monotonía, sino la heterogeneidad irreductible. Así, el ser humano ya no se presenta como un simple testaferro de la divinidad, como una mera determinación de la naturaleza, ni como el objeto preconcebido del progreso. La revelación poética pone en escena al hombre originario, al hombre creador:

La experiencia poética es una revelación de nuestra condición original. Y esa revelación se resuelve siempre en una creación: la de nosotros mismos. La revelación no descubre algo externo, que estaba ahí, ajeno, sino que el acto de descubrir entraña la creación de lo que va a ser descubierto: nuestro propio ser. $Y$ en este sentido sí puede decirse, sin temor a incurrir en contradicción, que 
el poeta crea al ser. Porque el ser no es algo dado, sobre lo cual se apoya nuestro existir, sino algo que se hace (Paz, 2014: 154).

Aquí se muestra la ambivalencia más importante del quehacer artístico: la obra de arte es a un tiempo creación y descubrimiento. No existe exterioridad entre ambas acciones. El hombre no descubre lo que está dado de antemano, ni crea lo que palidece frente a lo que realmente es. Quien crea, descubre; quien descubre, crea. Generación y verdad no son ya opuestos. El ser humano ya no se entumece en busca de una verdad ultraterrena, pues ha descubierto que no existe sino la verdad antropomorfa. El hombre no ha de renegar de sí mismo ni de su fecundidad para aspirar al ser, pues ahora reconoce que no hay ser ingénito: el ser es inseparable de su filiación humana.

Pero las consideraciones hasta aquí realizadas carecen de importancia si no se revelan a sí mismas en el arte vivo. Por ello bastará por el momento con interrogar a una obra elegida por motivos aparentemente circunstanciales: Los Boomerangs. Los sonidos, las formas y los tamańos desacompasados conspiran en los Boomerangs de Calder para reproducir la disparidad consustancial a la vida. Movimientos discontinuos, estelas irregulares, alteridad permanente; asimetría, disonancia, heterogeneidad; complejidad irreductible para los cánones de lo inequívoco. Una disparidad que sin embargo se muestra como el resultado de la composición creadora. Aquí lo dispar no resulta del ciego azar; no es ya la inhumana naturaleza la que se impone a la materia y al hombre, sino que es la insolencia creadora la que conforma su propio mundo.

Para Calder (1943), la simetría sólo es aceptada parcialmente a condición de contribuir con la desproporción del conjunto. Lo que este arte pone en movimiento es una impugnación a la autoridad de los cánones. Si los preceptos del "buen arte" sujetan la obra al imperio de la simetría, el artista ha de mostrar que las proporciones autorizadas no son más que un capricho. La disparidad no es así 
el resultado impensado de la torpeza amateur. El estadounidense recurre explícitamente a ella para dotar de vida sus composiciones. Esta asociación premeditada da cuenta de un hecho radical: lo propio de la vida no es la univocidad.

Calder va aún más allá de lo acostumbrado cuando recurre a materiales plebeyos. Prescindir de los materiales consagrados es también rechazar su ascendiente. El arte no se somete siquiera a la materia despótica. No es sólo a través de los materiales canónicos como se expresa lo otro; la equivocidad del ser es tan radical que puede presentarse hasta en los rincones más insospechados. $\mathrm{Al}$ igual que el poeta restituye la plenitud de su sentido a las palabras, el artista plástico rehabilita la deteriorada dignidad de sus materiales. No existe estrato de lo real capaz de negar su filiación humana.

Esta polémica es particularmente provocadora cuando "el arte" se refugia mecánicamente en una serie de formas convencionales. Ahí donde el uso rutinario de ciertas formalidades busca disimular su carácter arbitrario, controvertir el hábito se convierte en una necesidad vital. Así, la vivencia de la disparidad no se reduce a los límites de la obra individual, sino que se inserta en el seno mismo de la sociedad. No deja de ser paradójico que la composición ponga en escena la disparidad, pero ¿qué es la vida sino una heterodoxia originaria?

La genialidad creadora no se declara incompetente ante una ciega legalidad que se impone desde afuera, pero tampoco se refugia en una ortodoxia cuyo origen antropomorfo termina por desconocer. La equivocidad es ahora el producto de una expresión premeditada. Es la revelación que no reniega de su origen, sino que busca reconciliarse con él. La orfandad no se vive ya como una condena inexorable, sino como la condición de posibilidad de toda existencia. El arte es el Gran Rechazo porque reclama para mujeres y hombres el derecho de crear y recrear su propia realidad. 


\section{A manera de cierre}

La estética platónica se encuentra a una cuádruple distancia respecto al hombre. Tal alejamiento se expresa en el Edicto solemne dirigido a las almas que cuelga a la entrada del firmamento platónico:

El Rey Filósofo advierte a los ciudadanos de esta República que cualquier intento de contrabandear el más minimo resabio de existencia humana será castigado con todo el rigor de las leyes. Son causas especialmente graves de responsabilidad las siguientes 3 omisiones:

- Imitación profana (Fraude). Se entiende por imitación profana todo acto tendiente a adulterar la pureza del Ser. El Ser no reconoce ningún otro ni es compatible con lo mundano, asi que cualquier intento por alterar (pervertir) su inmaculada univocidad será duramente penado.

- Creatividad (Impiedad) Se entiende por creatividad toda apología profana al inicio o al fin. Dado que el ser es inmortal, y dado que la ausencia de finitud supone ausencia de principio, el monopolio de lo bello corresponde a la divinidad y es ingénito por definición.

- Equivocidad (Conspiración y motín) Se entiende por equivocidad todo uso público de la escritura. Las letras son incompatibles con lo inequivoco, y son conocidas por haber prestado ayuda a interpretaciones heterodoxas de la doctrina oficial. Su uso debe ser estrictamente personal.

Todas las pretensiones poetizantes deben de ceñirse al código de conducta de la República de las Formas, y deben de ser aprobadas con anterioridad por el Consejo de los Guardianes.

Según se desprende de la estética platónica, el hombre ha de poner en suspenso su humanidad para participar en el ser. No existe un arte propiamente humano en Platón, pues para aspirar a 
lo bello, el artista ha de comenzar por deshumanizarse. Hacer de lo bello lo absoluto, lo ingénito, lo inconciliable con la alteridad, conduce a renegar de lo mundano. Y si bien en esta solución se entrevé un rechazo al orden que aparece como dado, la solución es profundamente problemática para nuestra humanidad. Un arte de esta naturaleza conduce, en el mejor de los casos, al inmovilismo. En casos más severos (y este es el caso del platonismo), donde esta renuncia se confunde con la negación de la alteridad, el arte amenaza con convertirse en el portavoz de la maquinaria propagandista totalitaria.

¿Y cómo iba a ser de otra forma cuando al hombre se le fuerza a escoger entre plenitud y autonomía? No hay libertad que merezca tal nombre ahí donde el ser humano se amolda a un patrón absoluto. El hombre se resigna a ser un simple intermediario cuando es incapaz de reconocerse en sus productos. Sólo castrando su propia creatividad el hombre puede aspirar a un arte divino. Pero la fantasía de univocidad, al renegar de su origen antropomorfo, termina aniquilándose a sí misma. Hipostasiar lo inequívoco conduce a la reificación del hombre. Al desconocerse como el producto de una arbitrariedad, el ser humano se refugia en el más ciego de los consuelos. La ceguera autoinducida se convierte en el antídoto predilecto de quienes son incapaces de sobrellevar la angustia existencial. Quien anhela la eternidad de las verdades y la supresión de la alteridad bien puede reservar su lugar en la próxima venida del totalitarismo. El arte es una denuncia, pero una denuncia estéril si no se hace a nombre de la humanidad.

Tanto Platón como el Gran Rechazo reconocen la equivocidad consustancial a los materiales del artista. Pero mientras el platónico se da la vuelta aterrorizado frente a la precariedad de lo equívoco, el artista genuino reconoce en la alteridad la condición de posibilidad de toda libertad. La fidelidad al ser que procuraba con celo el platonismo era en realidad la más artera de las traiciones. Huir de 
la alteridad es renegar del hombre. Y sólo hay un ser: el que se origina ante la audacia humana que se sumerge en el abismo. La fidelidad al ser no es lo estático e inalterable, sino lo dispar, lo que está siempre en movimiento, lo que es siempre y radicalmente otro.

El arte no es la consumación de la libertad, pero sí es su promesa. Así lo expresa Paz cuando afirma que "el poema es vía de acceso al tiempo puro, inmersión en las aguas originales de la existencia" (Paz, 2014: 26). No son las palabras ordenadas y mutiladas las que expresan el ser, sino aquellas que exponen la naturaleza inasible e irreductible de la vida. Para alcanzar su verdad, las palabras y el resto de los productos de la historia no han de ser desechados como meras sombras del ser. Antes bien, han de ser liberados por la sublevación poética. En este acto de rebeldía, el artista no necesita refugiarse en lo divino, sino que comienza su lucha apelando a la alteridad originaria. Si la palabra misma es producto de una insolencia heterodoxa, si todo producto de la historia es una arbitrariedad, entonces invocar la ortodoxia no es más que un embuste. Los verdaderos responsables de la castración del ser no son aquellos que buscan reconciliarse con la abundancia originaria, sino quienes buscan imponer la ortodoxia por medio de la ablación semántica.

Apelar a un equívoco originario conlleva a reconocer la precariedad de toda configuración de lo sensible. Es así como el arte polemiza con el statu quo; es así como denuncia su arbitrariedad. La ambigüedad no es el fin último del arte, sino su arma liberadora. Para que el hombre repare en la condición provisoria de todo acontecer, el arte ha de señalar ese abismo sobre el cual se suspende el ser. Por ello, lo que se juega en la crítica a un arte suprahumano es el derecho a la autonomía. La fecundidad creadora se encuentra ahí donde hombres y mujeres se reconocen como los artífices de su propia historia. Tal y como señala Goethe: no hay otro responsable del sentido del mundo que el hombre mismo. Es el artista quien 
con sus versos pone en movimiento las fuerzas de la humanidad. No basta con rechazar la inevitabilidad del orden presente, sino que se ha de reclamar la autoría sobre lo que está por venir. Quien reclama su libertad ha de afrontar el peso insostenible de la angustia existencial; el insolente que desobedece a Dios ha de vivir el exilio. Pero ese decreto de expulsión es un precio que bien vale la pena pagar a cambio de lo posible.

\section{Bibliografía}

Aristóteles, 2002, Poética, Antonio López Eire (trad., pról., y notas), Istmo, Madrid.

Calder, Alexander, 1943, A Propos of Measuring a Mobile [Documento PDF], s/e. Disponible en: http://www.calder.org/system/downloads/1943-A-Propos.pdf (Consultado: 30/V/2018)

Marcuse, Herbert, 2005, El hombre unidimensional, Antonio Elorza (trad.), Ariel, Barcelona.

Paz, Octavio, 2014, El arco y la lira, FCE, México.

Platón, 2008, Diálogos I, Julio Calonge, Carlos García Gual y Emilio Lledó (trad., notas de), Gredos, Madrid.

, 2008, Diálogos III, Carlos García Gual, M. Martínez Hernández y Emilio Lledó (trad., intr., y notas), Gredos, Madrid. , 2006, La República, José Manuel Pabón y Manuel Fernández-Galiano (trad.), Alianza, Madrid. 